„w sobie” po „dziwiąc się", jak na przykład ks. J. Wujka: „i odszedł dziwując się sam w sobie temu, co się stało", chociaż Wulgata ma: „et abiit secum mirans quod factum fuerat", nowsze rosyjskie przekłady zawierają oba elementy: „i poszeł nazad, diwiat'sam w siebie" (Biblija. Knigi swiaszczennego pisanija Wietchogo i Nowego Zawieta, kanoniczeskije. Wyd. Amerykańskiego Towarzystwa Biblijnego, Nowy Jork b.r.w., cz. II, s. 98). Podobnie w wydaniu Nowego Testamentu Moskiewskiego Patriarchatu (Moskwa 1976, s. 206).

Byłoby ciekawym porównanie wersetu $9 \mathrm{z}$ Łk 24 w nowo odkrytym fragmencie jerozolimskim $\mathrm{z}$ odpowiednim wersetem $\mathrm{w}$ licznych nieopublikowanych starocerkiewnosłowiańskich i staroruskich Ewangeliach i aprakosach znajdujących się w bibliotekach radzieckich i w innych zbiorach.

Jakiekolwiek byłoby źródło omawianego wyżej wariantu, uważałem za stosowne donieść o tym specjalistom w dziedzinie krytyki tekstualnej Biblii. Być może, że któremuś $z$ nich poszczęści się i znajdzie odpowiedź na to pytanie.

Jerozolima

MOSHE ALTBAUER

Ks. Jerzy Chmiel

\title{
UZDROWIENIE OPĘTANEGO Z GERAZY W SZTUCE STAROCHRZESCIJAŃSKIEJ
}

Ikonografia starochrześcijańska może oddać wiele cennych usług dla egzegezy biblijnej nie tylko $z$ punktu widzenia historycznego zaświadczając, jakie perykopy biblijne były najczęściej przedmiotem religijnej medytacji za pomocą obrazów, lecz także wznosząc nowe, często zapomniane, aspekty widzenia takiej czy innej sceny biblijnej.

Niedawno (rok 1979) staraniem Papieskiej Komisji Archeologii Chrześcijańskiej odrestaurowano pieczołowicie fresk, dość już zniszczony, znajdujący się w tzw. solarium mauzoleum Marka Klodiusza Hermesa, jednego z trzech hipogeów grobowych (tzw. mauzoleum A) cmentarza św. Sebastiana przy Via Appia ${ }^{1}$. Fresk ten pochodzi z początku III w. i przedstawia w części centralnej postać klęczącego nagiego mężczyzny z rękoma wyciągniętymi w górę, na znak prośby,

1 C. Carletti, Una scena neotestamentaria della Roma sotterranea, w: „L'Osservatore Romano", 28 lipca 1979, s. 4. Por. A. Ferrua, S. Sebastiano e la sua catacomba, Roma (1968), s. 52. 
$\mathrm{w}$ stronę stojącej postaci, odzianej w białą tunikę $\mathrm{z}$ czerwonymi znamionami. Prawa strona fresku przedstawia trzodę świń rzucająca się $\mathrm{z}$ góry $\mathrm{w}$ przestrzeń o kolorze niebieskim, a więc niewątpliwie w wodę. Przed restauracją fresku nie można było zidentyfikować wszystkich szczegółów i dlatego wysuwano przypuszczenie o pogańskim pochodzeniu fresku. Po odnowieniu, kiedy wszystkie szczegóły malowidła wyszły na jaw, nie ulega wątpliwości, że chodzi tutaj o scenę ewangeliczną uzdrowienia opętanego z Gerazy.

Scena ta jest przedstawiona przez Synoptyków (Mt 8, 28-34; Mk 5, 1-20; モk 8, 26-39). Scena fresku została jednak oparta na wersji Łukaszowej: mianowicie opętany jest przedstawiony bez odzie-

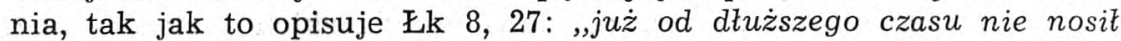
ubrania" (ouk enedysato himation). Powtórnie zwraca uwagę Łukasz na ten szczegół, gdy opisuje uzdrowionego, który siedział u nóg Jezusa już ubrany $(8,35)$. Otóż ten szczegół posłużył artyście do kompozycji całej sceny. Czy tutaj chodziło tylko o ekspresję nagiego ciała, czy też była jeszcze jakaś głębsza myśl? Można przypuszczać, że chodziło jeszcze o podkreślenie - podobnie jak w perykopie Łukaszowej - myśli, że owładnięcie człowieka przez złego ducha pozbawia go najbardziej podstawowych jego praw, do których należy zwykły przyodziewek. Chrystus uzdrawiając nieszczęśliwego przywraca mu jego ludzką godność i prawa człowieka.

Nowo odrestaurowany fresk jest najstarszym artystycznym przedstawieniem perykopy uzdrowienia Gerazeńczyka. Dotychczas bowiem, za Wilpertem, uważano, że malowidło z cmentarza św. Hermesa przy Via Salaria Vetus jest najstarszą malarską interpretacją tej perykopy ${ }^{2}$. Szczegółowa jednak analiza fresku z Via Salaria przeczy temu. Nie ma bowiem tam przedstawionego stada świń, a Chrystus ubrany w tunikę wyciąga ręce nad stojącą postacią nagiego mężczyzny. Stojąca postać jest w wyraźnej sprzeczności z przekazem Mk i $̇ k$ mówiących o pokłonie. Według obowiązującego schematu ikonograficznego na dekoracjach sarkofagów okresu konstantynopolitańskiego, byłoby to przedstawienie wskrzeszenia młodzieńca $z$ Nain (Ek 7, 11-17). Albo też byłaby to przedstawiona wersja Mateusza uzdrowienia jednego $\mathrm{z}$ dwóch opętanych, co jednak wydaje się mało prawdopodobne. W każdym razie omawiane malowidło z katakumb przy Via Salaria jest późniejsze od poprzedniego, pochodzi bowiem z 2 połowy IV w.

Tak więc fresk z mauzoleum Klodiusza Hermesa jest jedynym przynajmniej dotąd - ikonograficznym przedstawieniem tak sugestywnej perykopy o uzdrowieniu. Warto przypomnieć, że tę peryko-

2 Por. F. Wirth, Römische Wandmalerei vom Untergang Pompejis bis aus Ende des dritten Jahrhunderts, Darmstadt 1968, s. 192 n. Por. także B. Przybyszewski, Początki starochrześcijańskiej sztuki obrazowej, w: „Folia Historiae Artium” 15 (1979) 5-24. 
pę - i to w wersji Łukaszowej - przytacza w Biesach Dostojewski ${ }^{3}$, a niedawno zmarły Bogdan Ostromęcki napisal na jej temat ciekawe opowiadanie ${ }^{4}$.

Kraków

KS. JERZY CHMIEL

3 Ponadto $\mathrm{z}$ tej perykopy ( $\mathrm{Ek}$ 8, 32-36) bierze Dostojewski motto do Biesów. Por. J. Szymik, Ewangelia w wielkich powieściach Fiodora Dostojewskiego, praca magisterska, Kraków 1978 (archiwum PWT w Krakowie).

4 Uczeń, w: „Tygodnik Powszechny”, 12 sierpnia 1979, s. 4-5.

\section{Zdzisław J. Kapera}

\section{CURRICULUM VITAE KS. ALEKSEGO KLAWKA}

Celem mego krótkiego wprowadzenia do niniejszego posiedzenia ${ }^{1}$ jest przypomnienie w jak najzwięźlejszej formie głównych wydarzeń z życia ks. Aleksego Klawka, profesora Uniwersytetu Jagiellońskiego i Uniwersytetu Jana Kazimierza, członka Komisji Orientalistycznej Polskiej Akademii Umiejętności i członka-założyciela Komisji Orientalistycznej Polskiej Akademii Nauk. Mijają lata i coraz trudniej odtworzyć rzeczywiste daty i fakty dotyczące życia tego wybitnego uczonego. Mogłem się o tym przekonać poszukując materiałów do calendarium, które zamierzam przedstawić.

Przede wszystkim chciałbym zaznaczyć, że ks. prof. A. Klawek nie pozostawił po sobie niemal żadnych materiałów autobiograficznych ${ }^{2}$. Nie zachowała się również, z małymi wyjątkami, jego korespondencja ${ }^{3}$. Dla okresu młodości, dla jegó działalności w rodzinnej Wielkopolsce, pomoca służyło mi jedyne opracowanie źródłowe, bazujące przede wszystkim na aktach personalnych ks. A. Klawka w Kurii Poznańskiej, opublikowane przez ks. M. Wolniewicza na łamach 6-go numeru ,Ruchu Biblijnego i Liturgicznego" z r. 1970, numeru specjalnego, poświęconego pamięci ks. A. Klawka ${ }^{4}$. Pewne dodatkowe dane zawiera opublikowana podówczas książka M. Wolniewicza pt. Studium Pisma Swiętego w Arcybiskupim Seminarium Duchownym w Poznaniu w l. 1835-1939, Poznań 1969 (która w rzeczywistości wyszła z końcem 1970 r.). Dla rekonstrukcji okresu lwowskiego niezastapione pozostaje opracowanie Wydział Teologiczny Uniwersytetu Jana Kazimierza we Lwowie 1918-1933, Lwów 1934 i wspomnienie ks. W.

1 Tekst niniejszy wygłoszono na uroczystym posiedzeniu Komisji Orientalistycznej Krakowskiego Oddziału PAN w 10 rocznicę śmierci ks. prof. A. Klawka. Posiecizenie odbyło się w dn. 28 XI 1979 r.

: Jedyne dwa artykuly ks. A. Klawka zawierające elementy autobiograficzne to: Dawny wkiad Polski w Ziemie Odzyskane, Tyg. Powszechny 18, 1965, nr 39, s. 5 i Dzien Zaduszny w Forcie VII, Przewodnik Katolicki 1969, nr 44, s. 407.

: Nieliczne fragmenty korespondencji ks. A. Klawka (w odpisie) zachowały się we ,Wspomnieniach" ks. P. S t a c h a (rękopis niepublikowany).

4 M. Wolniew icz, Biblijna dziatalnośc $k s$. prof. Klawka w Wielkopolsce 1917-1923, RBL 23, 1970, 266-276. Por. też jego Wielkopolskie lata ks. profesora Klawka, „Przewodnik Katolicki", 76, 1970, nr 50, ss. 470-471. 